\title{
Azoxystrobin Rate and Timing Effects on Rice Head Blast Incidence and Rice Grain and Milling Yields
}

\author{
D. E. Groth, Professor, Rice Research Station, Louisiana Agricultural Experiment Station, LSU Agricultural Center, \\ 1373 Caffey Road, Rayne, LA 70578
}

\begin{abstract}
Groth, D. E. 2006. Azoxystrobin rate and timing effects on rice head blast incidence and rice grain and milling yields. Plant Dis. 90:1055-1058.

Growing blast susceptible rice (Oryza sativa) cultivars often requires farmers to use fungicides to prevent significant reductions in rice grain and milling yields. Studies were conducted to determine the optimum rate and rice growth stage for single or multiple applications of azoxystrobin to control blast (Pyricularia grisea). Azoxystrobin was applied foliarly to naturally infected field plots in 2001 to 2005 at rates of $0.11,0.17$, and $0.22 \mathrm{~kg}$ a.i. ha ${ }^{-1}$ at boot (B) and heading $(\mathrm{H})$ or only at $\mathrm{H}$ growth stages, and at $0.17 \mathrm{~kg}$ a.i. ha ${ }^{-1}$ at $5(\mathrm{H}+5), 10(\mathrm{H}+10)$, and $15(\mathrm{H}+15)$ days after $\mathrm{H}$ and $\mathrm{B}$ with low or high blast pressure. Head blast incidence (percent heads infected) was assessed 1 to 2 weeks before harvest. A fungicide application made at $\mathrm{H}, \mathrm{H}+5$, and $\mathrm{B}+\mathrm{H}$ significantly reduced blast incidence with high and low disease pressure, resulting in significantly higher grain and head rice milling yields compared with unsprayed plots with high blast pressure. There were no significant effects of fungicide rate on blast development or yield following the $\mathrm{H}, \mathrm{B}+\mathrm{H}$, and $\mathrm{H}+5$ applications. With fungicide applications made at $\mathrm{B}, \mathrm{H}+10$, and $\mathrm{H}+15$ days postheading, rice had higher disease incidence, resulting in lower grain and milling yields compared with rice receiving a heading application.
\end{abstract}

Additional keywords: application timing, reduced rate, yield loss

Rice blast, caused by the fungus Pyricularia grisea Sacc., is one of the most important rice (Oryza sativa L.) diseases worldwide (19). The teleomorph is Magnaporthe grisea (Hebert) Barr, but it is often referred to in the literature as $P$. oryzae Cavara. Under favorable conditions, it is a very important rice disease in the southern United States $(2,6,16)$. Severe blast has been attributed to susceptible cultivar, loss of flood water, high nitrogen fertilization, sandy light soils, and fields surrounded by trees $(3,8,13,14)$. These conditions often require farmers to use fungicides to prevent significant reductions in grain and milling yields.

In the United States, blast severity is often cyclic, with several years of high incidence followed by several years of low incidence $(6,15)$. Losses in grain and milling yields range from minimal to $80 \%$ and are dependent on inoculum pressure, crop growth stage at infection, environmental conditions, varietal resistance, and cultural management $(2,5,7,9)$. Prior to the strobilurin class of fungicides, fungicides were applied at both the boot and heading rice

Corresponding author: D. E. Groth

E-mail: dgroth@agcenter.lsu.edu

Accepted for publication 31 March 2006.

DOI: 10.1094/PD-90-1055

(C) 2006 The American Phytopathological Society growth stages to control blast (9). Since the labeling of azoxystrobin and trifloxystrobin, both highly efficacious against $P$. grisea, single applications are now used to control blast disease. Due to economic constraints, there has also been a trend toward reduced application rates. While strobilurin fungicides are more effective than benomyl, which is no longer labeled for this use in the United States $(8,9,12,15)$, they are expensive, and proper application timing is very critical. Benefits from fungicide applications include reduced disease development, reduced inoculum production, and increased grain and milling yields. Milling yield is a key component in grain quality and price. Consequently, forecasting systems have been developed for blast $(11,12)$, but fungicides are most often applied preventively based on presence of leaf blast or susceptibility of the cultivar in the United States.

Several fungicides are available to control blast worldwide, but most are not labeled in the United States (19). Azoxystrobin is the most commonly used rice fungicide in the southern United States (4). Information is limited on the optimum rates and timing of fungicide application for blast control as compared with sheath blight information $(4,8)$. Preliminary studies indicate the rate of azoxystrobin required to effectively control blast changes as disease incidence varies with the susceptibility of the host (9). Azoxystrobin is most commonly applied at the boot growth stage for control of sheath blight, the most important rice disease in the southern United States $(6,18)$. However, azoxystrobin is most effective in controlling blast when applied at heading. Consequently, there has been a general trend to make a single application of azoxystrobin later in the season to attempt to control both blast and sheath blight. A major problem with delaying fungicide applications to the heading growth stage is this stage is often misidentified or missed, resulting in less effective applications for sheath blight (4). Detrimental effects of postheading applications on blast control are also suspected because of the narrow period of time the rice head can be infected by the blast pathogen. The objective of this study was to determine the proper rates and timings of azoxystrobin to maximize blast control, grain, and milling yields on susceptible and very susceptible cultivars.

\section{MATERIALS AND METHODS}

Experiments were conducted at the LSU Agricultural Center Rice Research Station in Crowley, LA. Plots were drill-seeded using the very susceptible cultivar M202 (2001, 2002, 2005) and the susceptible cultivars LaGrue (2002) and Bengal (2004 and 2005) on 30, 25, and 29 April in 2001, 2002, and 2005, respectively, and 7 May 2004, at the rate of $112 \mathrm{~kg}$ seed ha-1 . Plots were 1.2 by $4.9 \mathrm{~m}$ consisting of seven rows at $18-\mathrm{cm}$ spacing. Soil type was a Crowley silt loam (pH 6.0, clay $12 \%$, silt $71 \%$, sand $17 \%$, CEC $9.4 / \mathrm{kg}$ ). Fertilizer was incorporated at the rate of $20-60-60 \mathrm{~kg} \mathrm{ha}^{-1}$ of $\mathrm{N}$ P-K 1 day before planting. Agronomic, weed, and insect management practices followed current standard recommendations (1). Plots were fertilized preflood with $133 \mathrm{~kg} \mathrm{~N}^{-1}$ as urea at the three- to four-leaf stage and postflood at the rate of $24 \mathrm{~kg} \mathrm{~N} \mathrm{ha}^{-1}$ as ammonium sulfate at the beginning of stem internode elongation (green ring). To encourage disease development, plots were drained during the tillering growth stage until the soil cracked, and then reflooded.

Fungicide treatments. Azoxystrobin (Quadris 2.08 SC, Syngenta, Raleigh, NC) was applied at $0.11,0.17$, and $0.22 \mathrm{~kg}$ a.i. $\mathrm{ha}^{-1}$, the most common rates used commercially, as two applications at boot (5- to $10-\mathrm{cm}$ panicle in the boot) (B) and heading (50 to $70 \%$ of heads emerging from the boot) $(\mathrm{H})$ and as single applications at $\mathrm{H}$. Additional treatments included azoxy- 
strobin at $0.17 \mathrm{~kg}$ a.i. $\mathrm{ha}^{-1}$ applied at $\mathrm{B}$ and 5, 10, and 15 days after heading $(\mathrm{H}+5$, $\mathrm{H}+10$, and $\mathrm{H}+15)$. Treatments were applied at a delivery rate of 140 liters ha ${ }^{-1}$ with a $\mathrm{CO}_{2}$ backpack sprayer. Dates of applications to 'M202' were B: 3 July 2001, 13 June 2002, and 1 July 2005; H: 13 July 2001, 25 June 2002, and 12 July 2005; H+5: 18 July 2001, 10 July 2002, and 18 July 2005; H+10: 23 July 2001, 15 July 2002, and 22 July 2005; and H+15: 28 July 2001, 20 July 2002, and 27 July 2002. Dates of application for 'LaGrue' and 'Bengal' were B: 10 July 2001, 22 July 2004, and 11 July 2005; H: 16 July 2001, 28 July 2004, and 21 July 2005; H+5: 20 July 2001, 1 August 2004, and 26 July 2005; H+10: 26 July 2001, 6 August 2004, and 1 August 2005; and H+15: 31 July 2001, 11 August 2004, and 5 August 2005. An unsprayed control (light to severe disease, similar to commercial fields not treated with fungicides) was included for comparison.

Disease assessments and yield determination. Plots were evaluated for blast development approximately 1 to 2 weeks before maturity by examining 25 tillers at four locations in the center four rows of each plot and calculating the percent symptomatic heads. Evaluations were made on 9 August 2001, 26 July 2002, and 3 August 2005 for 'M202' and on 9 August 2001, 27 August 2004, and 8 August 2005 for 'LaGrue' and 'Bengal'.

On 20 August 2002, 8 August 2004, and 18 August 2005 for 'M202', and 20 August 2002, 30 August 2004, and 28 August 2005 for 'LaGrue' and 'Bengal', the center four rows of each plot were harvested with a small-plot rice combine. Grain yields and moisture were determined, and rice grain yields were adjusted to $12 \mathrm{~g} \mathrm{~kg}^{-1}$ moisture. A 125 -g grain subsample was collected from each harvest sample for determining milling percentages of whole (unbroken kernels) and total rice (broken and whole grains). The subsample was hulled with a McGill Sheller, setting 19 (RAPSCO,
Brookshire, TX), to remove the lemma and palea. The resulting brown rice was then processed in a McGill Miller (RAPSCO) for $30 \mathrm{~s}$ to remove the bran layers and part of the embryo. The milled sample was weighed to determine total milled yield percentages and then placed on a Grainman grain separator (Grain Machinery Manufacturing Corporation, Miami, FL) with no. 10 then no. 11 plates for the long grain ('LaGrue') or no. 135 then no. 10 plates for the medium grains ('M202' and 'Bengal') to remove broken kernels. Whole kernels were then weighed to determine whole milling or head rice. Milling yield percentages were calculated as [(weight/125)*100]. Head rice milling yield was considered commercially acceptable if it met the standard industry values for rice of $55 \%$ head rice and $70 \%$ total rice.

Data analysis. Treatments were replicated four times and arranged in a randomized complete block with a new randomization pattern each year. Statistical analyses were performed using mixed model $F$ tests, and when significant $(P=$ $0.05)$ treatment effects were detected, orthogonal contrasts were constructed to compare treatment means in each factor. An LSD was calculated for each variable for mean comparisons. Statistical analyses were conducted using SAS version 8 (SAS Institute, Cary, NC).

\section{RESULTS}

Disease development and effect of azoxystrobin treatments. Leaf blast developed approximately 7 to 10 days after drainage on all cultivars. Infection level appeared severe enough to justify treatment for blast in commercial fields $(1,7)$. No other known yield-reducing disease was noticed in the plots. Severe blast developed uniformly each year on 'M202', primarily as neck blast (45 to $91 \%$ heads infected); however, less severe blast developed on 'LaGrue' and 'Bengal' (6 to $27 \%$ heads infected) (Tables 1 and 2). Year by treatment interactions were not significant $(P=0.05)$, and results are presented as 3year averages. The average percent heads infected with blast in the heavily infected rice ranged from 32 to $69 \%$ (Table 1). All fungicide treatments, except the $\mathrm{B}, \mathrm{H}+10$, and $\mathrm{H}+15$ applications, reduced percent heads infected compared with the unsprayed control. On 'LaGrue' and 'Bengal', average of percent heads infected with blast was lower, ranging from 8 to $17 \%$ in the unsprayed control (Table 2). All fungicide treatments reduced heads infected compared with the unsprayed control. Comparing different azoxystrobin rates applied at $\mathrm{B}+\mathrm{H}$ and $\mathrm{H}$ revealed no significant differences in percent heads infected under severe or less severe disease levels (Tables 1 and 2). There were no significant differences in disease development between one application at $\mathrm{H}$ or two at $\mathrm{B}+\mathrm{H}$ under different disease severity levels (Tables 1 and 2). Comparing azoxystrobin timing at $0.17 \mathrm{~kg}$ a.i. $\mathrm{ha}^{-1}$ revealed that average blast incidence increased when applications were delayed, with applications at $\mathrm{H}+10$ and afterward having significantly higher percent heads infected than applications at $\mathrm{H}$ (Table 1). Boot applications were not as effective as $\mathrm{H}$ applications when disease was severe.

Grain yield and quality. Year by treatment interactions were not significant $(P=$ 0.05 ), and results are presented as 3-year averages. Under severe disease conditions, the best fungicide treatment, $0.17 \mathrm{~kg}$ a.i. $\mathrm{ha}^{-1}$ azoxystrobin at $\mathrm{B}$ and $\mathrm{H}$, resulted in rice grain yields $2,518 \mathrm{~kg} \mathrm{ha}^{-1}$ higher than the inoculated control (Table 1). The B, $\mathrm{H}+10$, and $\mathrm{H}+15$ applications did not significantly increase yield (Table 1). Under less severe disease conditions, rice grain yield following the best fungicide treatment was $1,165 \mathrm{~kg} \mathrm{ha}^{-1}$ more than the inoculated control (Table 2). Again, the $\mathrm{H}+10$ and $\mathrm{H}+15$ applications did not significantly increase yield (Table 2). Azoxystrobin rate did not significantly affect yield for applications made at $\mathrm{B}+\mathrm{H}$ or $\mathrm{H}$

Table 1. Control of blast head infections by foliar azoxystrobin (Quadris 2.08 SC) fungicide applications and resulting yield and milling quality as compared with an unsprayed control at different rates and timings under severe disease ${ }^{\mathrm{a}}$

\begin{tabular}{|c|c|c|c|c|c|c|}
\hline \multirow[b]{2}{*}{ Treatment } & \multirow{2}{*}{$\begin{array}{c}\text { Timing of } \\
\text { application }^{\mathbf{b}}\end{array}$} & \multirow{2}{*}{$\begin{array}{c}\text { Fungicide rate } \\
\left(\mathrm{kg} \mathrm{a.i.}^{-1} \mathbf{h a}^{-1}\right)\end{array}$} & \multirow{2}{*}{$\begin{array}{c}\text { Infected } \\
\text { heads }(\%)\end{array}$} & \multirow{2}{*}{$\underset{\left(\mathrm{kg} \mathrm{ha}^{-1}\right)}{\text { Yield }}$} & \multicolumn{2}{|c|}{ Rice milling (\%) } \\
\hline & & & & & Head & Total \\
\hline Unsprayed & & & 67 & 3,749 & 40.1 & 59.2 \\
\hline Azoxystrobin & B & 0.17 & 59 & 4,620 & 42.3 & 58.7 \\
\hline Azoxystrobin & $\mathrm{H}$ & 0.22 & 37 & 5,569 & 52.4 & 63.2 \\
\hline Azoxystrobin & $\mathrm{H}$ & 0.17 & 34 & 5,983 & 51.8 & 64.5 \\
\hline Azoxystrobin & $\mathrm{H}$ & 0.11 & 45 & 5,258 & 47.9 & 62.1 \\
\hline Azoxystrobin & $\mathrm{B}$ and $\mathrm{H}$ & 0.22 & 32 & 6,254 & 50.2 & 62.8 \\
\hline Azoxystrobin & $\mathrm{B}$ and $\mathrm{H}$ & 0.17 & 32 & 6,267 & 51.9 & 63.7 \\
\hline Azoxystrobin & $\mathrm{B}$ and $\mathrm{H}$ & 0.11 & 38 & 5,930 & 49.9 & 62.8 \\
\hline Azoxystrobin & $\mathrm{H}+5$ & 0.17 & 47 & 5,119 & 48.8 & 61.8 \\
\hline Azoxystrobin & $\mathrm{H}+10$ & 0.17 & 60 & 4,007 & 43.9 & 58.7 \\
\hline Azoxystrobin & $\mathrm{H}+15$ & 0.17 & 69 & 3,677 & 43.1 & 59.1 \\
\hline $\operatorname{LSD}(P=0.05)$ & & & 19 & 1,110 & 7.1 & 4.5 \\
\hline
\end{tabular}

a Means are 3-year averages of small-plot field tests conducted using 'M202' at the Rice Research Station, Crowley, LA. Years are 2001, 2002 , and 2005.

${ }^{\mathrm{b}}$ Application timings used were B (boot, i.e., 5- to 10 -cm panicle in the shoot), $\mathrm{H}$ (heading, i.e., 70 to $80 \%$ of panicles emerging), and $\mathrm{H}+5$, $\mathrm{H}+10$, and $\mathrm{H}+15$ $(5,10$, and 15 days after heading). 
(Table 2). Although two applications resulted in higher yield than single application under severe disease pressure, application number had no impact on yield at lower disease pressure.

Head rice milling yields were commercially unacceptable (standard industry values for rice are at least $55 \%$ head rice and $70 \%$ total rice) in all treatments under severe disease conditions but were acceptable in all treatments where disease pressure was less severe (Table 2). Boot and post $\mathrm{H}$ fungicide application were less effective than applications made at $\mathrm{H}$, resulting in lower grain and milling yields (Tables 1 and 2). With heavy disease pressure, most fungicide treatments had significantly higher whole grain milling yield than the unsprayed control except the B, $\mathrm{H}+10$, and $\mathrm{H}+15$ treatments (Table 1). With light disease pressure, only the head rice millings associated with the two application treatments at $\mathrm{B}+\mathrm{H}$ were significantly higher than the unsprayed control. Fungicide rate did not affect whole grain milling yield at either level of disease pressure.

With high disease pressure, total milling yield was not affected as greatly as head rice yields and was only significantly higher than the unsprayed control when the $0.17 \mathrm{~kg}$ a.i. ha ${ }^{-1}$ rate was applied at $\mathrm{H}$ and $\mathrm{B}+\mathrm{H}$ and the $0.22 \mathrm{~kg}$ a.i. ha ${ }^{-1}$ at $\mathrm{H}$. With low blast pressure, there were no significant treatment effects on total milling.

\section{DISCUSSION}

Percent infected heads from natural inoculum varied greatly in these experiments based on the year and variety. Blast caused significant grain and milling yield reductions to rice plants in unsprayed plots as compared with rice in most sprayed plots. The difference between the best fungicide treatment and the unsprayed control indicated that blast caused at least a $40 \%$ grain yield loss with an additional 23\% reduction in whole grain milling yield on the highly susceptible 'M202' but much less on 'LaGrue' and 'Bengal'. However, even the reductions on the less susceptible 'LaGrue' and 'Bengal' are very important to the economic return a rice producer would receive from his crop. Under current economic conditions, this loss is over $\$ 181 \mathrm{ha}^{-1}$. Disease levels and yield reductions noted here are comparable with previous studies conducted in small plots and commercial fields $(3,9,10)$.

Blast was not effectively controlled with azoxystrobin. Regardless of disease severity, approximately $50 \%$ blast control was obtained with a single $(\mathrm{H})$ or two $(\mathrm{B}+\mathrm{H})$ applications of azoxystrobin. Lower control occurred with $\mathrm{B}$ and post $\mathrm{H}$ applications. Fungicide rate did not significantly affect yield response from the $\mathrm{B}+\mathrm{H}$ or $\mathrm{H}$ stage applications. Yield increases were greater with higher disease pressure. All 'M202' treatments yielded less than any of the treatments applied to 'Bengal' and 'LaGrue', including the unsprayed control. In the absence of blast, yield potential of 'M202' is equal to or greater than 'Bengal', indicating the severe yield loss encountered in this trial. Lower yield increases were produced with high and low rates and with single and double applications with low disease pressure. The cost of using the lowest rate tested, $\$ 31.12 \mathrm{ha}^{-1}$ based on the 2005 price for azoxystrobin, represents a substantial savings over the cost of using the highest rate tested, $\$ 62.24 \mathrm{ha}^{-1}$. Boot and post $\mathrm{H}$ fungicide applications were less effective in disease control and increasing yields than applications made at $\mathrm{H}$. Delaying fungicide application could also result in the introduction of more inoculum into the field that could cause additional late-season infections and further reduce yields. It is possible that B application did reduce inoculum in these plots; however, inoculum from adjacent unsprayed plots produced large quantities of spores that negated the spore reduction by
B application. Overall control by azoxystrobin was probably underestimated due to this interplot interference from the spore pressure from unsprayed plots, which could also explain similar results in small plots compared with field tests observed by Greer and Webster (3) in California. However, best results have always been obtained when some part of the head was exposed $(3,9,13,17)$.

It is not surprising that post $\mathrm{H}$ fungicide applications allowed more disease development because most blast infections usually occur at or just after head emergence while plant tissues are most susceptible (16). This would also explain why post $\mathrm{H}$ fungicide applications did not protect yield and grain quality because blast damages the plant's ability to transport nutrients to the filling grain (16) and fungicides applied after infection would not protect yield. Azoxystrobin timing was more critical with high blast pressure than with low (Table 1).

Producers often delay blast fungicide applications until after $\mathrm{H}$ because the growth stage is easily missed unless they enter the field and examine individual plants. Late applications (post $\mathrm{H}$ ) also result in reduced sheath blight control, resulting in significant reductions in yield and milling comparable with late blast applications $(5,6)$. A short period of only a few days in application timing can make a great difference in rice yield and quality. Producers in Louisiana are now encouraged to monitor growth stages as they scout for diseases to maximize returns from fungicide applications (4).

The results from these studies were based on susceptible cultivars grown in small plots. Caution generally is recommended when extrapolating small plot data to field situations, although trends demonstrated in small plot research typically translate to commercial field management $(3,8,13)$. This is especially true when multiple tests are conducted over several years.

Table 2. Control of blast head infections by foliar azoxystrobin (Quadris R $2.08 \mathrm{SC}$ ) fungicide applications and resulting yield and milling quality as compared with an unsprayed control at different rates and timings under less severe disease ${ }^{\mathrm{a}}$

\begin{tabular}{|c|c|c|c|c|c|c|}
\hline \multirow[b]{2}{*}{ Treatment } & \multirow{2}{*}{$\begin{array}{c}\text { Timing of } \\
\text { application }^{\mathrm{b}}\end{array}$} & \multirow{2}{*}{$\begin{array}{c}\text { Fungicide rate } \\
\left(\text { (kg a.i. }^{-1} \mathbf{a}^{-1}\right)\end{array}$} & \multirow{2}{*}{$\begin{array}{c}\text { Infected } \\
\text { heads }(\%)\end{array}$} & \multirow{2}{*}{$\begin{array}{c}\text { Yield } \\
\left(\mathrm{kg} \mathrm{ha}^{-1}\right)\end{array}$} & \multicolumn{2}{|c|}{ Milling (\%) } \\
\hline & & & & & Head & Total \\
\hline Unsprayed & $\ldots$ & $\ldots$ & 17 & 7,733 & 58.9 & 68.9 \\
\hline Azoxystrobin & B & 0.17 & 10 & 8,399 & 60.8 & 69.7 \\
\hline Azoxystrobin & $\mathrm{H}$ & 0.22 & 10 & 8,575 & 60.9 & 69.3 \\
\hline Azoxystrobin & $\mathrm{H}$ & 0.17 & 9 & 8,441 & 61.2 & 69.8 \\
\hline Azoxystrobin & $\mathrm{H}$ & 0.11 & 9 & 8,397 & 60.4 & 69.7 \\
\hline Azoxystrobin & $\mathrm{B}$ and $\mathrm{H}$ & 0.22 & 8 & 8,898 & 61.7 & 70.1 \\
\hline Azoxystrobin & $\mathrm{B}$ and $\mathrm{H}$ & 0.17 & 8 & 8,668 & 61.6 & 69.8 \\
\hline Azoxystrobin & $\mathrm{B}$ and $\mathrm{H}$ & 0.11 & 9 & 8,664 & 62.3 & 70.4 \\
\hline Azoxystrobin & $\mathrm{H}+5$ & 0.17 & 11 & 8,373 & 61.1 & 69.4 \\
\hline Azoxystrobin & $\mathrm{H}+10$ & 0.17 & 11 & 8,275 & 61.3 & 69.5 \\
\hline Azoxystrobin & $\mathrm{H}+15$ & 0.17 & 11 & 8,101 & 60.3 & 69.9 \\
\hline $\operatorname{LSD}(P=0.05)$ & & & 5 & 639 & 2.2 & NS \\
\hline
\end{tabular}

a Means are 3-year averages of small-plot field tests conducted using 'LaGrue' and 'Bengal' at the Rice Research Station, Crowley, LA. Years are 2001, 2004 , and 2005.

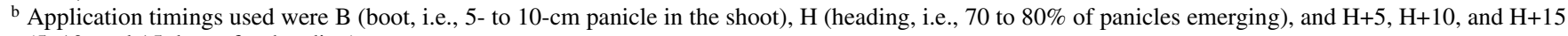
(5, 10, and 15 days after heading). 
Yield increases due to fungicide applications and levels of disease development were similar between the Rice Research Station and commercial rice fields $(5,6)$.

Fungicide applications have been commonly used in southern Louisiana rice production $(3,9)$. In the past, two fungicide treatments were often needed to effectively control blast (9), but with the labeling of more effective fungicides and economic constraints that limit the number of applications, a single application approach is now the most common scenario. This study showed that good control was possible with a single application of azoxystrobin made at $\mathrm{H}$. Currently, the Quadris label does not recommend lower rates, but results from this study suggest that lower rates may be justified in some circumstances. However, timing is critical since waiting to apply fungicide after heading can allow blast to develop to a point that the application cannot prevent significant yield and milling losses. Lower than labeled rates can be legally used without special labeling, but nonperformance complaints may not be supported by agricultural companies.

This study demonstrated that producers can control blast and improve rice grain and milling yields by applying azoxystrobin once at $\mathrm{H}$, but two applications at $\mathrm{B}+\mathrm{H}$ were more effective. Rates of $0.11,0.17$, and $0.22 \mathrm{~kg}$ a.i. $\mathrm{ha}^{-1}$ were equally effective when applied at either $\mathrm{H}$ or $\mathrm{B}$ and $\mathrm{H}$ under high and low blast pressure. Applications at B and 10 to 15 days after $\mathrm{H}$ were not as effective as those made at $\mathrm{H}$.

\section{ACKNOWLEDGMENTS}

I thank Jason Bond and Richard Dunand for reviewing this manuscript and giving many helpful suggestions. I also thank the Louisiana Rice Research Board and Syngenta for providing support for this research and publication. I appreciate Marty Frey and Joe Nugent for their hard work and assistance in conducting these studies. Approved for publication by the Director of the Louisiana Agricultural Experiment Station as manuscript number 06-61-0029.

\section{LITERATURE CITED}

1. Anonymous. 1999. Louisiana Rice Production Handbook. LSU Agricultural Center. Pub. No. 2321, Revised.

2. Bonman, J. M. 1992. Blast. Pages 14-17 in: Compendium of Rice Diseases. R. K. Webster and P. S. Gunnell, eds. American Phytopathological Society, St. Paul, MN.

3. Greer, C. A., and Webster, R. K. 2001. Occurrence, distribution, epidemiology, cultivar reaction, and management of rice blast disease in California. Plant Dis. 85:1096-1102.

4. Groth, D. E. 2005. Azoxystrobin rate and timing effects on rice sheath blight incidence and severity and rice grain and milling yields. Plant Dis. 89:1171-1174.

5. Groth, D. E. 1996. Two new fungicides to control rice diseases. La. Agric. 39:31-33.

6. Groth, D., and Lee, F. 2003. Rice diseases. Pages 413-456 in: Rice Origin, History, Technology, and Production. C. W. Smith and R. H. Dilday, eds. John Wiley \& Sons, Hoboken, NJ.

7. Groth, D. E., Rush, M. C., Giesler, G. G., and Hollier, C. A. 1993. Foliar fungicides for use in the management of rice diseases. La. Agric. Exp. Stn. Bull. No. 840.

8. Groth, D. E., Rush, M. C., and Hollier, C. A. 1991. Rice diseases and disorders in Louisiana. La. Agric. Exp. Stn. Bull. No. 828.

9. Groth, D. E., Rush, M. C., and Lindberg, G. D. 1990. Foliar fungicides for control of rice diseases in the United States. Pages 31-52 in: Pest Management in Rice. B. T. Grayson, M. B. Green, and L. G. Copping, eds. Elsevier, London.
10. Hollier, C. A., Groth, D. E., Levy, R. J., Courville, B. A., and McCorry, J. C. 1994. Rice yield differences: A comparison of fungicide application methods. Proc. Rice Tech. Wrkg. Grp. 25:88-89.

11. Ishiguro, K., and Nanseki, T. 2000. Exploring optimum application programs of fungicide using a simulator for leaf blast epidemics. Pages 203-208 in: Advances in Rice Blast Research. D. Tharreau, M. Lebrum, N. J. Talbot, and J. L. Notteghem, eds. 1998. Vol. 15, Developments in Plant Pathology. Kluwer Academic Publishers, Boston.

12. Kim, C. H., MacKenzie, D. R., and Rush, M. C. 1988. Field testing a computerized forecasting system for rice blast disease. Phytopathology 78:931-934.

13. Lee, F. N. 1994. Rice breeding programs, blast epidemics, and blast management in the United States. Pages 489-500 in: Rice Blast Disease. R. S. Zeigler, S. A. Leong, and P. S. Teng, eds. CAB International, Wallingford, UK.

14. Long, D. H., Lee, F. N., and TeBeest, D. O. 2000. Effect of nitrogen fertilization on disease progress of rice blast on susceptible and resistant cultivars. Plant Dis. 84:403-409.

15. Marchetti, M. A., Rush, M. C., and Hunter, W. E. 1976. Current status of rice blast in the southern United States. Plant Dis. Rep. 60:721-725.

16. Ou, S. H. 1985. Rice Diseases. 2nd ed. Commonw. Mycological Institute, Kew, England.

17. Seebold, K. W., Jr., Datnoff, L. E., CorreaVictoria, F. J., Kucharek, T. A., and Snyder, G. H. 2004. Effects of silicon and fungicides on the control of leaf and neck blast in upland rice. Plant Dis. 88:253-258.

18. Van Eeckhout, E., Rush, M. C., and Blackwell, M. 1991. Effects of rate and timing of fungicide applications on incidence and severity of sheath blight and grain yield of rice. Plant Dis. 75:1254-1261.

19. Yamaguchi, I. 2004. Overview on the chemical control of rice blast disease. Pages 1-13 in: Rice Blast: Interaction with Rice and Control. S. Kawasaki, ed. Kluwer Academic Publishers, Dordrecht, The Netherlands. 